\title{
Intracranial Embryonal Tumor, Not Otherwise Specified
}

National Cancer Institute

\section{Source}

National Cancer Institute. Intracranial Embryonal Tumor, Not Otherwise Specified. NCI

Thesaurus. Code C5817.

A central nervous system embryonal tumor, not otherwise specified arising from the brain. 